\title{
Akuntabilitas dan Tingkat Korupsi Pemerintah Kabupaten dan Kota Di Provinsi Jawa Tengah
}

\author{
Lia Pramesti \\ Haryanto \\ Departemen Akuntansi, Fakultas Ekonomika dan Bisnis, Universitas Diponegoro Semarang \\ haryantogege@gmail.com
}

\begin{abstract}
This research is motivated by the increase of corruption level in developing countries and the lack of the government audit institutions' role in reducing corruption. This research is aimed to provide an empirical evidence of accountability on eradicating the corruption in regency and city government of Central Java. The components of accountability observed are audit findings and audit opinions and tehir impacts eradication of corruption in regency and city government of Central Java. The method used in this research is a quantitative approach. The writer uses the secondary data of all regency and city government in Central Java from 201 to 2017 and analyzes it using multiple linear regression method. The result shows that audit findings have significant positive effects on corruption and audit opinion has no impact on the corruption in regency and city government in Central Java.
\end{abstract}

Keywords: Accountability, audit findings, audit results, corruption

\begin{abstract}
Abstrak
Latar belakang penelitian ini adalah peristiwa korupsi yang terus meningkat di negara-negara berkembang dan kurangnya peran lembaga audit pemerintah dalam mengurangi korupsi. Penelitian ini bertujuan untuk memberikan bukti empiris tentang akuntabilitas dalam memberantas korupsi di pemerintah kabupaten dan kota di Jawa Tengah. Komponen pertanggungjawaban yang penulis amati adalah temuan audit dan opini audit serta dampaknya terhadap pemberantasan korupsi kabupaten dan pemerintah kota di Jawa Tengah. Metode yang digunakan dalam penelitian ini adalah pendekatan kuantitatif. Penulis menggunakan data sekunder dari semua kabupaten dan pemerintah kota di Jawa Tengah dari 2014-2017 dan menganalisanya menggunakan metode analisis regresi linier berganda. Hasil penelitian menunjukkan bahwa temuan audit berpengaruh positif signifikan terhadap korupsi dan opini audit tidak berpengaruh terhadap korupsi di pemerintah kabupaten dan kota di Jawa Tengah.
\end{abstract}

Kata Kunci: Akuntabilitas, temuan audit, hasil audit, korupsi

\section{PENDAHULUAN}

Salah satu masalah yang harus diselesaikan di negara berkembang adalah masalah korupsi (Olken, 2007). Bukan hanya mengambil sejumlah uang, tetapi tindakan kecil yang mengarah ke tindakan korupsi dilakukan oleh pemegang kekuasaan di Indonesia untuk menyejahterakan dirinya sendiri. Meskipun pemerintah telah melakukan beberapa usaha untuk mengurangi terjadinya korupsi, pelaku korupsi di kalangan pemerintah terus bermunculan setiap tahunnya (Henderson \& Kuncoro, 2011). Hal ini menyebabkan citra pemerintah menjadi buruk serta turut memiskinkan negara (Deny, 2018).

Reformasi pada tahun 1998 berusaha untuk menjadikan pemerintahan di Indonesia menjadi lebih demokratis dan mengedepankan kesejahteraan masyarakat tetapi belum menyediakan solusi bagi korupsi di Indonesia (Sherlock, 2010). Salah satu buah dari reformasi tersebut adalah Undang-Undang Nomor 22 Tahun 1999 yang mengatur tentang Otonomi Daerah yang diimplementasikan hingga saat ini.

Otonomi daerah yang diimplementasikan sebagai langkah desentralisasi adalah salah satu faktor penyebab korupsi (Maulani, 2010), padahal desentralisasi seharusnya menjadi langkah pemerintah mencapai good governance (Lessmann \& Markwardt, 2010). Hal ini sesuai dengan 
penelitian oleh Donal Fariz yang menyatakan bahwa otonomi daerah mengakibatkan korupsi oleh Bupati maupun Walikota di kalangan pemerintah daerah, diakibatkan banyaknya dana yang dipercayakan kepada pemerintah daerah membuat oknum-oknum tergoda untuk melakukan tindakan korupsi (Wardah, 2013).

Salah satu contoh pelaksanaan otonomi daerah adalah dengan mengurus semua hal yang berkaitan dengan keuangan sektor publik di daerah tersebut secara mandiri. Adanya urusan keuangan pemerintah daerah seperti dalam sektor pengelolaan aset nasional, penganggaran, pengadaan, serta perpajakan membuat semua pihak yang berperan dalam urusan keuangan ingin mendapatkan keuntungan pribadi dengan cara yang kotor (Liu \& Lin, 2012). Perilaku ini menunjukkan bahwa perwujudan akuntabilitas publik melalui pelaporan keuangan pemerintah daerah berjalan dengan buruk seiring banyaknya korupsi yang terjadi oleh oknum-oknum di pemerintahan.

Transparency International Indonesia (TII) menyatakan bahwa Indonesia pada tahun 2017 mendapat predikat sebagai negara terkorup khususnya di wilayah Asia-Pasifik (Muliana, 2017). Indonesia masih bertahan dalam zona merah selama 5 tahun terakhir seperti yang dikatakan oleh TII. Selama satu dekade terakhir, Indonesia mengalami kerugian material sebesar Rp 205 triliun (Ant, 2016). Sangat mungkin bagi Indonesia mendapatkan predikat sebagai salah satu negara terkorup di dunia (Prabowo, 2016).

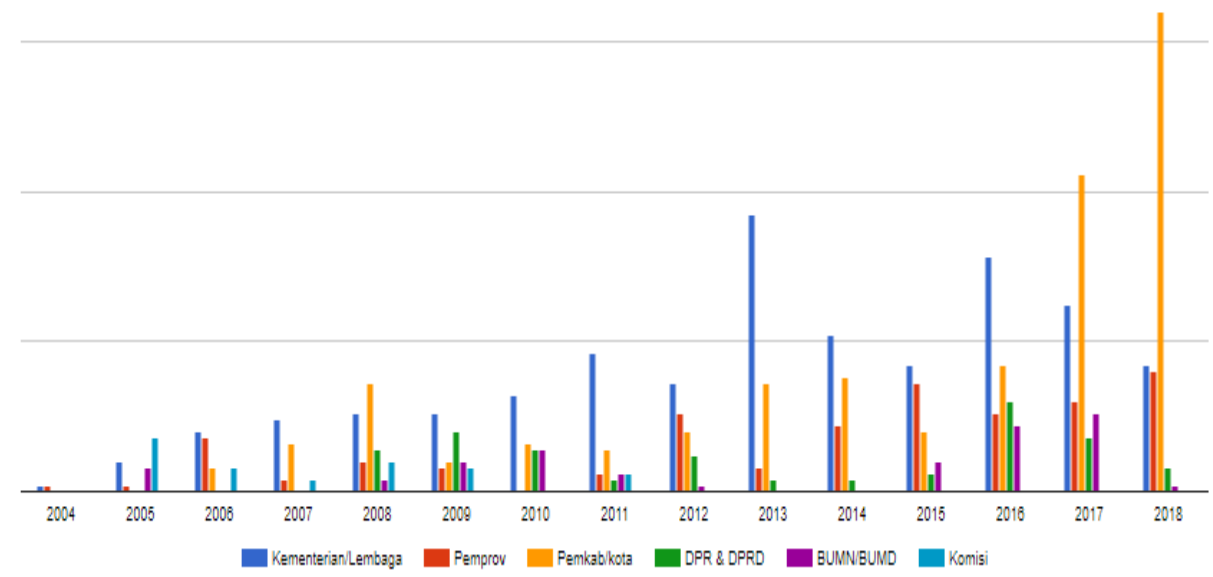

Gambar 1. Jumlah Kasus Korupsi yang Terjadi di Lembaga Pemerintahan

Selama empat tahun terakhir, Indonesia mengalami peningkatan kasus korupsi khususnya di lembaga pemerintahan yaitu Pemerintah Kabupaten dan Kota. Pada tahun 2017 Indonesia mendapatkan nilai indeks persepsi korupsi sebesar 37 dari 100 dan berada di posisi 96 dari 180 negara (Transparency International, 2017). Laporan tren Indonesia Corruption Watch tahun 2017 juga menyatakan kasus korupsi tertinggi terjadi di lembaga pemerintah kabupaten sebanyak 222 peristiwa dan pemerintah kota sejumlah 45 kasus dengan total kerugian sebanyak Rp 1,362 triliun (Indonesia Corruption Watch, 2017). Hal ini menjadikan pemerintah harus berusaha lebih keras untuk mengurangi terjadinya korupsi (Iskandar, 2018).

Menurut Laporan Tren Penindakan Kasus Korupsi Tahun 2017 yang dikeluarkan oleh ICW modus korupsi yang sering dilakukan oleh pelaku korupsi dan ditangani oleh penegak hukum adalah penyalahgunaan anggaran dengan nilai kerugian negara sebesar $\mathrm{Rp}$ 1,2 triliun dari 154 kasus. Namun, nilai kerugian negara paling besar terjadi pada modus penyalahgunaan wewenang. Salah satu kasusnya adalah pemberian Izin Pinjam Pakai Kawasan Hutan (IPPKH) serta penyalahgunaan menyangkut ekspor nikel oleh PT Kemakmuran Pertiwi Tambang yang merugikan keuangan negara sekitar Rp 630 miliar.

Korupsi bisa disebabkan oleh adanya dorongan seseorang untuk melakukan penyelewengan. Salah satunya adalah adanya kekuasaan yang membentuk sebuah monopoli yang dimanfaatkan untuk membuat kebijakan yang mendukung tujuan seseorang atau kelompok tertentu. Hal inilah yang mengakibatkan menjamurnya praktik korupsi karena adanya pemanfaatan kekuasaan, monopoli kebijaksanaan, serta akuntabilitas yang tidak kuat (Klitgaard, 
1997). Upaya untuk mengurangi terjadinya tindakan korupsi adalah dengan perwujudan akuntabilitas publik yang baik bagi penyelenggara urusan pemerintahan (Shah, 2007).

Pembuatan laporan keuangan adalah suatu bentuk kebutuhan transparansi yang merupakan syarat pendukung adanya akuntabilitas yang berupa keterbukaan pemerintah atas aktivitas pengelolaan sumber daya publik. Transparansi informasi terutama informasi keuangan dan fiskal harus dilakukan dalam bentuk yang relevan dan mudah dipahami oleh masyarakat (Schiavo-Campo and Tomasi, 1999). Dengan adanya opini audit atas LKPD maka masyarakat diharapkan mampu menilai kinerja pemerintah daerahnya. Apabila perwujudan akuntabilitas lewat pembuatan LKPD mendapatkan opini yang baik, maka dapat dipastikan tata kelola pemerintah daerah tersebut sudah terlaksana dengan baik. Hal ini menunjukkan tidak adanya penyelewengan yang mengarah ke tindakan korupsi (Afriyanti, Sabanu, \& Noor, 2015).

Banyak hal yang sudah dibuat oleh pemerintah untuk mencegah terulangnya peristiwa korupsi dengan membentuk lembaga-lembaga seperti BPK, BPKP, Inspektorat, dan KPK. Lembaga ini diharapkan mampu mengurangi ketidakefisienan dan penyalahgunaan dalam pemanfaatan sumber daya organisasi (Dwiputrianti, 2008). Jika pengawasan dan tata kelola pemerintahan buruk maka akan timbul tindakan korupsi yang disebabkan oleh sumber daya manusia publik yang dimiliki disalahgunakan oleh oknum tertentu (Olken, 2007). Oleh karena itu, perlu adanya pemeriksaan dalam fungsi audit sehingga mampu mendeteksi adanya tindakan kecurangan (Olken, 2007). Korupsi di pemerintah daerah dapat diketahui melalui proses audit yang dilakukan oleh lembaga audit yang memiliki kapasitas untuk mengawasi dan terlibat dalam aspek akuntabilitas pemerintah (Gong, 2009). Audit juga mampu menunjukkan adanya wilayah yang berpeluang terjadinya tindakan korupsi.

Alasan diperlukannya penelitian ini adalah kondisi darurat Indonesia karena kasus korupsi meningkat tiap tahunnya serta pelaksanaan otonomi daerah yang dianggap sebagai ladang untuk melakukan tindakan yang berpeluang melakukan merugikan negara. Alasan lainnya yaitu karena peran audit pemerintah belum maksimal dalam meningkatkan akuntabilitas pemerintah daerah untuk mengurangi terjadinya kasus korupsi, walaupun saat ini audit pemerintah diandalkan untuk memberantas korupsi (Suhardjanto, 2018).

Penelitian sebelumnya dilakukan oleh Liu dan Lin (2012) pada pemerintah daerah di seluruh provinsi di Cina dengan menganalisis peran audit pemerintahan dengan menggunakan temuan audit dan usulan tindak lanjut untuk mendeteksi potensi korupsi di pemerintahan. Hasil penelitiannya menunjukkan bahwa jumlah deteksi pelanggaran aturan oleh badan audit lokal berpengaruh secara positif dengan tingkat korupsi di suatu provinsi, dan perbaikan pasca audit berpengaruh secara negatif dengan tingkat korupsi di suatu provinsi. Penelitian lain juga dilakukan oleh Mogiliansky (2014) yang berfokus kepada akuntabilitas pegawai negeri sipil yang melakukan tindakan korupsi dikarenakan adanya kekuatan untuk mengalokasikan sumber daya untuk produksi dan mengalihkan sejumlah uang untuk dirinya sendiri.

Penelitian ini dikembangkan dari penelitian oleh Liu dan Lin (2012) dengan mengganti objek penelitian berupa pemerintah kabupaten dan kota di Provinsi Jawa Tengah serta menambah variabel penelitian berupa opini audit yang tidak diteliti pada penelitian sebelumnya. Opini audit dalam penelitian ini ditambahkan sebagai indikator perwujudan akuntabilitas pemerintah daerah melalui LKPD yang diaudit oleh BPK. Penelitian ini juga akan menilai akuntabilitas melalui peran audit pemerintah dalam upayanya memberantas korupsi yang mencakup periode tahun 2014 -2017 sebagai sampel terutama karena peningkatan tingkat korupsi selama empat tahun terakhir berturut-turut dan didominasi dengan peningkatan kasus korupsi yang terjadi di pemerintah daerah di Indonesia (www.antikorupsi.org, 2015).

\section{TELAAH LITERATUR DAN PENGEMBANGAN HIPOTESIS Teori Klitgaard}

Teori Klitgaard atau teori monopoli dikemukakan oleh Robert Klitgaard. Dalam teori ini, korupsi adalah $\mathrm{C}=\mathrm{M}+\mathrm{D}-\mathrm{A}$. Klitgaard menyebutkan bahwa monopoli dengan kekuasaan pejabat dalam membuat kebijaksanaan tanpa akuntabilitas yang baik akan mengarah pada motivasi untuk melakukan korupsi. Penelitian ini akan menggunakan salah satu aspek Teori Klitgaard yaitu akuntabilitas. Akuntabilitas sangat berkaitan dengan tata kelola perusahaan atau organisasi yang menunjukkan kewajiban pihak yang berwenang dalam hal pengambilan keputusan dan kebijakan (Gong, 2009). Akuntabilitas menjadi salah satu pengurang korupsi setelah adanya desentralisasi kekuasaan (Klitgaard, 1997). Kualitas pemerintah dapat dilihat dari akuntabilitas pemerintahannya dalam upaya mengurangi tindakan korupsi (Mardiasmo, 2009). Semakin rendahnya akuntabilitas maka semakin banyak kasus korupsi yang terjadi dan 
menandakan bahwa pemerintah dinilai kurang berkualitas (Gupta, Davoodi, \& Alonso-terme, 2002). Korupsi yang dilakukan oleh aktor pemerintah dikarenakan adanya kemampuan dalam mengalokasikan sumberdaya masyarakat yang kemudian digunakan untuk kesejahteraan pribadi (Gupta et al., 2002).

\section{Tingkat Korupsi}

Secara umum korupsi dianggap sebagai "benalu" dalam suatu sistem dan organisasi yang merugikan dan menyebabkan pemubaziran dalam penggunaan sumber daya di suatu negara (Monteduro, Hinna, \& Moi, 2016). Menurut Association of Certified Fraud Examiners (ACFE), penyuapan, konflik kepentingan antar pihak, pemerasan dalam hal ekonomi, pemberian uang hadiah di luar gaji yang ilegal adalah cabang yang menguraikan korupsi (Tuanakotta, 2012).

Sumber daya manusia yang berkualitas rendah sebagai pegawai pemerintahan di negara berkembang adalah salah satu hal yang menyumbang kegagalan pemerintahan karena ketidakmampuan dalam melaksanakan akuntabilitas pemerintahannya. Tidak mengagetkan jika terdapat banyak kasus korupsi di negara berkembang yang dilakukan oleh pegawai pemerintahannya sendiri (Klitgaard, 1997). Masyarakat menjadi korban utama adanya kasus korupsi di kalangan pemerintahan karena uang yang dibayarkan lewat pajak telah hilang namun pelayanan publik yang ada kualitasnya pun berkurang (Suhardjanto, 2018). Korupsi juga menyebabkan efek berkepanjangan seperti inefisiensi penyelenggaraan kegiatan pemerintah, proses demokrasi yang menurun, terpuruknya pembangunan ekonomi, menjamurnya gelandangan, serta terjadinya degradasi moral negeri (Suhardjanto, 2018).

\section{Korupsi}

Menurut Undang-Undang Nomor 31 Tahun 1999, korupsi adalah tindakan seseorang menyalahi peraturan yang berlaku untuk menyejahterakan dirinya sendiri, orang lain dan perusahaan, menyalahgunakan kekuasaan, kesempatan, atau mempergunakan sarana dan prasarana dalam kelompok tersebut yang dimiliki oleh negara dan merugikan urusan ekonomi dan keuangan suatu negara. Kemudian Undang-Undang Nomor 20 Tahun 2001 menguraikan ada 30 tindakan yang termasuk jenis korupsi yang dikelompokkan daam 7 golongan yaitu (1) pemberian barang atau materi yang sifatnya ilegal; (2) berbuat tidak jujur atau melakukan kecurangan; (3) penyalahgunaan kekuasaan; (4) ruginya negara dalam hal material; (5) penyuapan; (6) memeras atau mengancam orang lain; serta (7) menggunakan jabatan untuk kepentingan pribadi dalam hal pengadaan.

Tindakan korupsi dapat diselidiki oleh kejaksaan, kepolisian, hingga KPK. Dalam tindakan penyelidikan yang dilakukan oleh KPK biasanya muncul tindakan-tindakan yang termasuk dalam tindakan korupsi yang biasanya terjadi ketika pemberian keterangan oleh saksi maupun terdakwa yaitu: (a) mencegah penyelidikan kasus korupsi; (b) tidak memberikan keterangan atau menyatakan kasus tidak terjadi, (c) rincian akun pembukuan tersangka tidak diberikan oleh bank, (d) informasi palsu yang diberikan oleh ahli maupun saksi, (e) tindakan diam atau kebohongan yang diberikan oleh pemegang kekuasaan, dan (f) identitas pelapor dilaporkan oleh saksi (Komisi Pemberantasan Korupsi, 2006).

\section{Akuntabilitas dan Laporan Keuangan Pemerintah Daerah}

Otonomi daerah memaksa pemerintah agar mampu melaksanakan akuntabilitas pemerintahannya dengan baik dan mandiri (Gong, 2009). Salah satunya dengan mengimplementasikan hak dan kewajiban pemerintah daerah dalam meningkatkan akuntabilitas sehingga masyarakat akan percaya karena mengutamakan kepentingan dan kebutuhan rakyatnya (Moisiu, 2014).

Akuntabilitas publik dapat dinilai dengan melihat akuntabilitas keuangan sebuah laporan. Bentuk pertanggungjawaban akan aspek keuangan, pengukuran, pengungkapan, dan kepatuhan merupakan bagian dari akuntabilitas keuangan (Mardiasmo, 2009). Banyak akuntabilitas dinilai berdasarkan laporan yang dibuat oleh pemerintah daerah yang berisi tentang pendapatan, belanja serta simpanan sektor pemerintah yang sudah disiapkan secara baik (BPKP, 2018).

Akuntabilitas publik dinilai oleh lembaga independen seperti BPK. Hal ini dilakukan untuk mencegah terjadinya penyelewengan sumber daya maupun kekayaan dalam konteks tindakan korupsi (Dwiputrianti, 2008). BPK akan melaksanakan fungsi audit hingga mengeluarkan opini audit sebagai hasil audit yang dapat digunakan untuk menilai ada atau tidakya kegiatan penyelewengan yang mengarah ke tindakan korupsi di pemerintah daerah (Liu \& Lin, 2012). 
Selain sebagai alat untuk mencegah dan mendeteksi tindakan korupsi, audit pemerintah juga ditujukan untuk meningkatkan kemampuan akuntabilitas pemerintah daerah dan tanggung jawabnya (Laffan \& Laffan, 2011). Tidak hanya penilaian laporan keuangan, tetapi juga audit pemerintah berperan untuk mengendalikan dan memantau dalam rangka akuntabilitas pemerintah (Gong, 2009). Serangkaian proses audit seringkali akan menemukan hal-hal yang mencurigakan seperti penggendutan akun beban, nominal belanja-belanja yang tidak masuk akal, serta alokasi sumber daya yang tidak jelas tujuannya (Olken, 2007). Maka, besar harapan pemerintah dalam melaksanakan audit pemerintah sebagai sistem resistensi yang mampu mencium gelagat, dan menghapuskan korupsi (Liu \& Lin, 2012).

Dalam berbagai penelitian, salah satunya oleh Liu dan Lin (2012), tujuan utama dari mengaudit pemerintah sebagai badan yang memiliki kekuatan untuk mengendalikan aspek-aspek penting adalah untuk mengamati, meyakinkan, dan memberikan nilai akuntabilitas penyelenggaraan pemerintahnya. Untuk itu demi tercapainya laporan keuangan pemerintah daerah yang akuntabel dan transparan sesuai dengan Undang-Undang Nomor 15 Tahun 2004, audit pemerintah dilaksanakan oleh lembaga independen yang ditunjuk pemerintah yaitu Badan Pemeriksa Keuangan (BPK). Undang-Undang Nomor 15 Tahun 2004 lebih lanjut mengatur mengenai kriteria pemberian opini oleh BPK yang sesuai dengan standar atau peraturan akuntansi yang berlaku di pemerintahan (SAP), adanya pengungkapan yang cukup (adequate disclosures), kepatuhan terhadap undang-undang, dan sistem pengendalian internal yang berjalan efektif. Opini tersebut kemudian akan disebutkan dalam Laporan Hasil Pemeriksaan yang menunjukkan tingkat akuntabilitas pemerintah daerah yang semuanya disimpulkan dalam IHPS setiap semesternya.

\section{Pengembangan Hipotesis \\ Temuan Audit dan Tingkat Korupsi}

Proses audit yang dilakukan oleh BPK Republik Indonesia akan menghasilkan temuan audit yang berisi tentang temuan yang berkaitan dengan pengendalian internal serta temuan atas ketidakpatuhan pemerintah terhadap aturan-aturan yang berlaku (Suhardjanto, 2018). Temuan audit tersebut bermanfaat bagi pemerintah untuk mendapatkan rekomendasi pengendalian internalnya sekaligus mengetahui terjadinya kecurangan dan kesalahpahaman (Agustiningsih, Murni, \& Putri, 2017). Salah satu hal yang diperhatikan dalam pemerintahan adalah pengendalian internalnya, karena dengan pengendalian internal yang kuat maka tidak akan terjadi tindakan kecurangan (Huefner, 2011). Selain itu kepatuhan terhadap peraturan dan hukum yang diterapkan akan mengurangi tindakan korupsi dan kecurangan yang terjadi dalam semua organisasi maupun lembaga (Raman \& Wilson, 2014). Salah satu aspek dari akuntabilitas adalah temuan audit yang berisikan tentang kelemahan pada sistem pengendalian hingga pada peraturan yang berlaku dan hal ini menunjukkan kelemahan akuntabilitas yang berpotensi tinggi menyebabkan korupsi (BPK, 2012). Adanya peraturan serta kepatuhan pemerintah daerah mampu meningkatkan akuntabilitas yang dianggap penting dalam mengurangi kasus korupsi (Ferraz \& Finan, 2010).

Penelitian tentang temuan audit dan tingkat korupsi dilakukan pada tahun 2012 di Cina menemukan adanya hubungan positif antara korupsi dan temuan audit (Liu \& Lin, 2012). Hasil ini menunjukkan bahwa temuan audit atas kelemahan sistem pengendalian internal dan ketidakpatuhan terhadap hukum menambah jumlah pelaku kasus korupsi (Liu \& Lin, 2012). Penelitian tersebut berisi lebih banyak ketidakpatuhan terhadap peraturan di pemerintah daerah di Cina mengarah ke tingkat korupsi yang lebih tinggi, sehingga mengurangi kualitas laporan keuangan yang dibuat (Liu \& Lin, 2012). Penelitian lain yang dilakukan oleh Suhardjanto (2018) menemukan adanya pengaruh positif antara temuan audit dan tingkat korupsi sehingga memberikan keyakinan dalam penyusunan hipotesis penelitian sebagai berikut:

$\mathrm{H}_{1}$ : Temuan audit memiliki pengaruh positif pada tingkat korupsi.

\section{Hasil Audit (Opini Auditor) dan Tingkat Korupsi}

Opini auditor menggambarkan tiga hal pokok yang disiapkan oleh pemerintah. Pertama, dalam memberikan hasil audit atas laporan keuangan berupa opini auditor akan menggambarkan 'keandalan' akan kandungan informasi dalam laporan tersebut (Suhardjanto, 2018). Kedua, auditor menyatakan opininya sebagai bentuk manifestasi 'tingkat akuntabilitas' akan laporan keuangan (Suhardjanto, 2018). Ketiga, ketika auditor menyatakan pendapat atau opininya maka hal ini dianggap sebagai indikator kewajaran dari pengungkapan laporan keuangan (Suhardjanto, 2018).

Teori Klitgaard menyatakan bahwa tingkat kewajaran dan keadilan laporan keuangan dinilai berdasarkan opini yang dikeluarkan auditor. Hal ini terkait dengan akuntabilitas dan 
memiliki pengaruh pada tingkat korupsi (Klitgaard, 1997). Pemerintah daerah yang akuntabel akan lebih rendah menjumpai kasus korupsi di daerahnya (Shah, 2007). Dalam penelitian sebelumnya, belum terdapat opini auditor dalam menilai akuntabilitas pemerintah daerah dan tingkat korupsi. Oleh karena itu, hipotesis disusun seperti berikut:

$\mathrm{H}_{2}$ : Opini auditor memiliki pengaruh negatif terhadap tingkat korupsi.

\section{METODE}

\section{Variabel Penelitian dan Definisi Operasional Variabel}

Penelitian ini menggunakan variabel dependen berupa tingkat korupsi dan dua variabel independen yaitu temuan audit dan opini audit. Dalam penelitian ini juga terdapat variabel kontrol yaitu ukuran pemerintahan untuk menetralkan pengaruh yang ditimbulkan terhadap variabel tingkat korupsi. (lihat Tabel 1).

\section{Populasi dan Sampel}

Populasi yang digunakan dalam penelitian ini adalah seluruh pemerintah daerah dan kota di Pulau Jawa khususnya Provinsi Jawa Tengah tahun 2014 hingga 2017 sebagai populasi yang saat ini ada 6 pemerintah kota dan 29 pemerintah kabupaten. Metode penentuan sampel yang digunakan adalah purposive sampling. Kriteria penentuan sampel yang digunakan dalam penelitian ini adalah sebagai berikut: (1) Pemerintah daerah kota dan kabupaten yang mempunyai opini dari BPK RI dan memiliki jumlah temuan audit. (2) pemerintah daerah kabupaten dan kota yang mempunyai Kejaksaan Negeri Republik Indonesia yang menangani tindak pidana korupsi (3) pemerintah daerah kabupaten dan kota yang memiliki data pada tahun anggaran 2014-2017 yang lengkap untuk seluruh variabel.

Tabel 1. Variabel, Jenis, Indikator, dan Skala Pengukuran

\begin{tabular}{|c|c|c|}
\hline Variabel & Jenis & Indikator \\
\hline Tingkat korupsi & Terikat & $\begin{array}{l}\text { Diukur dengan menghitung jumlah kasus korupsi yang ditangani } \\
\text { oleh Kejati RI yang ada di setiap pemerintah kabupaten dan kota } \\
\text { di Provinsi Jawa Tengah per } 10.000 \text { penduduk. Skala pengukuran } \\
\text { variabel ini menggunakan rasio yang datanya diperoleh dari } \\
\text { Laporan Tahunan Kejaksaan Agung RI tahun } 2014-2017 \text { (Liu) }\end{array}$ \\
\hline Temuan audit & Bebas & $\begin{array}{l}\text { Diukur dengan menggunakan total jumlah temuan audit yang } \\
\text { ditemukain dalam proses audit oleh BPK RI berupa temuan atas } \\
\text { SPI maupun temuan atas pelanggaran perundang-undangan (Liu) }\end{array}$ \\
\hline Opini audit & Bebas & $\begin{array}{l}\text { Diukur dengan menggunakan variabel dummy, } 1 \text { jika } \\
\text { mendapatkan opini Wajar Tanpa Pengecualian dan } 0 \text { untuk opini } \\
\text { selain WTP. (1) }\end{array}$ \\
\hline Ukuran Pemerintahan & Kontrol & $\begin{array}{l}\text { Ukuran pemerintahan ditumjukkan berdasarkan proporsi total } \\
\text { realisasi belanja dengan Produk Domestik Bruto (Liu) }\end{array}$ \\
\hline
\end{tabular}

\section{Metode Analisis dan Uji Hipotesis}

Penelitian ini menggunakan metode analisis regresi berganda untuk pengujian hipotesis karena alasan penggunaan lebih dari 2 variabel independen untuk mengetahui variabelvariabel tersebut memiliki pengaruh atau tidak (Ghozali, 2006). Persamaan yang digunakan untuk menganalis regresi berganda dalam penelitian ini yaitu:

Keterangan:

$$
\text { CORRUPTm,n }=\alpha o+\beta_{1} A U I R R m, n+\beta_{2} A U O P I m, n+\beta_{3} \text { GOVSIZEm,n }+\varepsilon
$$

CORRUPTm,n : Tingkat korupsi kabupaten atau kota $m$ tahun ke-n

$\alpha \mathrm{O}$

$\boldsymbol{\beta}_{1} \boldsymbol{\beta}_{2} \boldsymbol{\beta}_{3}$

AUIRRm,n

AUOPIm,n GOVSIZEm,n

$\varepsilon$

\section{: Konstanta}

: Koefisien regresi

: Temuan audit di pemerintah kabupaten atau kota $m$ tahun ke-n

: Opini auditor di pemerintah kabupaten atau kota $m$ tahun ke-n

: Ukuran pemerintah pemerintah kabupaten atau kota $m$ tahun $n$

: Error atau galat 


\section{HASIL DAN PEMBAHASAN \\ Deskripsi Objek Penelitian}

Populasi dalam penelitian ini adalah seluruh pemerintah kabupaten dan kota di Provinsi Jawa Tengah pada tahun 2014-2017 sebanyak 29 pemerintah kabupaten dan 6 pemerintah kota. Perincian perolehan sampel penelitian dapat dilihat pada Tabel 2.

Tabel 2. Sampel Penelitian Periode 2014-2017

Kriteria Sampel

Jumlah Pemerintah

Jumlah pemerintah kabupaten dan kota di Provinsi Jawa Tengah x 4 tahun

Dikurangi data outlier

Jumlah sampel akhir penelitian

\section{Statistik Deskriptif}

Analisis statistik deskriptif memberikan gambaran atau deskripsi suatu data yang dilihat dari nilai rata-rata (mean), standar deviasi, varian, nilai maksimun, dan nilai minimum (Ghozali, 2011). Analisis deskriptif digunakan untuk memberikan gambaran dan deskripsi variabel-variabel yang digunakan dalam penelitian ini.

Tabel 3. Statistik Deskriptif

\begin{tabular}{lrrrrr}
\hline & N & \multicolumn{1}{c}{ Minimum } & \multicolumn{1}{c}{ Maximum } & \multicolumn{1}{c}{ Mean } & \multicolumn{1}{c}{ Std. Deviation } \\
\hline AUIRR & 126 & .06 & .89 & .179 & .13303 \\
AUOPI & 126 & .00 & 1.00 & .627 & .48554 \\
GOVSIZE & 126 & .02 & .16 & .0889 & .03103 \\
CORRUPT & 126 & .01 & .40 & .0883 & .07126 \\
Valid N (listwise) & 126 & & & & \\
\hline
\end{tabular}

\section{Hasil Uji Asumsi Klasik}

Hasil uji normalitas menunjukkan hasil distribusi yang normal baik grafik histogram maupun hasil uji one-sampel Kolmogorov-Smirnov yang menunjukkan nilai signifikannya lebih dari 0,05 (Tabel 4). Hasil uji multikolinearitas menunjukkan bahwa semua model regresi memiliki nilai VIF yang kurang dari 10 dan nilai tolerance lebih dari 0,10 (Tabel 5). Hasil uji heteroskedastisitas dengan uji Glejser menunjukkan tidak ada satupun variabel yang memiliki hubungan dengan nilai absolut residualnya pada taraf 0,05 (Tabel 6). Hasil analisis regresi diperoleh nilai DW sebesar 1,955. Dengan demikian menunjukkan bahwa model regresi yang digunakan bebas dari autokorelasi.

Tabel 4. Hasil Uji One-Sample Kolmogorov-Smirnov

\begin{tabular}{lr}
\hline & Unstandardized Residual \\
\hline $\mathrm{N}$ & 129 \\
Kolmogorov-Smirnov Z & 1.118 \\
Asymp. Sig. (2-tailed) & .164 \\
\hline
\end{tabular}

Tabel 5. Hasil Uji Multikolinearitas

\begin{tabular}{lccc}
\hline & Model & \multicolumn{2}{c}{ Model } \\
\cline { 2 - 4 } & \multicolumn{2}{c}{ Tolerance } & VIF \\
\hline (Constant) & & \\
AUIRR & .983 & 1.017 \\
AUOPI & .986 & 1.014 \\
GOVSIZE & .996 & 1.004 \\
\hline
\end{tabular}


Tabel 6. Hasil Uji Heteroskedastisitas

\begin{tabular}{|c|c|c|}
\hline Variabel & $\mathrm{T}$ & Sig \\
\hline AUIRR & 0,401 & 0,689 \\
\hline AUOPI & 0,063 & 0,482 \\
\hline GOVSIZE & 0,421 & 0,675 \\
\hline
\end{tabular}

\section{Hasil Uji Simultan (Uji F)}

Uji statistik F pada dasarnya menunjukkan apakah semua variabel independen yang dimasukkan dalam model mempunyai pengaruh secra bersama-sama terhadap variabel dependen, dan untuk menguji apakah model regresi yang digunakan sudah tepat. Model regresi dalam penelitian ini memiliki nilai $\mathrm{F}$ hitung sebesar 18,363 dan signifikan kurang dari 0,05 . Hal ini menunjukkan bahwa model regresi dalam penelitian ini memiliki variabel independen secara bersama-sama mempengaruhi variabel dependen dalam setiap model regresi. Model regresi dalam penelitian ini fit untuk menguji pengaruh temuan audit dan opini audit terhadap tingkat korupsi. Selain itu nilai adjusted $R^{2}$ pada model regresi dengan variabel dependen tingkat korupsi sebesar 0,294 . Hal ini berarti kemampuan variabel independen yaitu temuan audit dan opini audit dan kombinasi keduanya dalam menjelaskan variasi tingkat korupsi adalah sebesar 29,4 persen. berikut:

Tabel 7 menunjukkan hasil uji t sehingga diperoleh persamaan regresi adalah sebagai

$$
\text { CORRUPTi,t }=0,065+0,283(\text { AUIRRi,t) }-0,007(\text { AUOPIi,t })+0,26(\text { GOVSIZEi,t) }+\stackrel{a}{\circ}
$$

Tabel 7. Hasil Uji Statistik t

\begin{tabular}{lrrr}
\hline Model & B & \multicolumn{2}{c}{ S } \\
\hline (Constant) & 0.065 & 3.287 & .001 \\
AUIRR & .283 & 6.909 & .000 \\
AUOPI & -0.007 & -0.635 & .527 \\
GOVSIZE & .260 & 1.504 & .135 \\
\hline
\end{tabular}

\section{Pengaruh Temuan Audit terhadap Tingkat Korupsi}

Variabel temuan audit dalam penelitian ini menggunakan jumlah temuan audit oleh BPK baik temuan tentang sistem pengendalian internal maupun ketidakpatuhan atas perundangundangan yang disesuaikan dengan jumlah penduduk. Hasil uji hipotesis 1 menunjukkan bahwa temuan audit mempunyai pengaruh positif signifikan terhadap tingkat korupsi (koefisien regresi $0,283, p<0,05)$. Hasil pengujian tersebut memiliki kesamaan dengan hipotesis yang telah dirumuskan sebelumnya bahwa temuan audit memiliki pengaruh terhadap tingkat korupsi karena nilai signifikansinya kurang dari 0,05 . Penelitian ini selaras dengan penelitian yang dilakukan sebelumnya oleh Liu dan Lin (2012) dimana temuan audit memiliki pengaruh positif terhadap korupsi pada provinsi-provinsi di Negara Cina.

Dalam mendeteksi kecurangan yang mengarah pada tingkatan korupsi, pemerintah berfokus pada pengendalian internal yang ada dalam pemerintah kabupaten maupun kota tersebut karena pengendalian internal yang baik maka tindakan kecurangan akan jarang terjadi (Huefner, 2011). Selain itu temuan audit atas ketidakpatuhan terhadap perundang-undangan juga memiliki pengaruh terhadap tingkat korupsi. Hal ini dikarenakan apabila pemerintah kabupaten maupun kota banyak melakukan tindakan yang melanggar undang-undang atau peraturan hukum maka dapat menimbulkan tindakan kecurangan yang mengarah pada meningkatnya tindakan korupsi yang menyebabkan kerugian pada negara serta berkurangnya kualitas laporan keuangan yang telah dibuat.

\section{Pengaruh Opini Audit terhadap Tingkat Korupsi}

Pengukuran variabel opini audit dalam penelitian ini menggunakan variabel dummy dengan memberikan nilai 1 pada Opini Wajar Tanpa Pengecualian dan 0 pada opini non-WTP. Penelitian ini menemukan bahwa opini audit tidak memiliki pengaruh terhadap tingkat korupsi koefisien regresi sebesar $-0,007, \mathrm{p}>0,05)$. Hasil penelitian ini juga sejalan dengan Suhardjanto 
(2018) yang menyatakan adanya pengaruh negatif opini audit terhadap tingkat korupsi yang dilakukan oleh pemerintah kabupaten dan kota.

Opini yang diberikan oleh Badan Pemeriksa Keuangan mengandung beberapa arti yaitu laporan keuangan yang diperiksa menggambarkan keandalan informasi dalam laporan tersebut (Suhardjanto, 2018). Opini tersebut adalah bentuk manifestasi dari tingkat akuntabilitas suatu laporan keuangan dan pernyataan bahwa laporan keuangan tersebut disusun secara wajar (Suhardjanto, 2018).

Menurut Teori Klitgaard, tingkat kewajaran dan keadilan laporan keuangan dinilai berdasarkan opini yang dikeluarkan auditor, hal ini terkait dengan akuntabilitas dan memiliki pengaruh pada tingkat korupsi (Klitgaard, 1997), sedangkan pemerintah daerah yang akuntabel akan lebih rendah menjumpai kasus korupsi di daerahnya (Shah, 2007). Maka dapat dikatakan semakin akuntabel sebuah pemerintah kota maupun kabupaten maka semakin baik pula opini yang diberikan oleh BPK sehingga, semakin baik opini maka semakin rendah tindakan korupsi dilakukan pada pemerintah kabupaten atau kota tersebut.

\section{Hasil Uji Variabel Kontrol}

Pengukuran variabel kontrol ukuran pemerintahan dalam penelitian ini adalah dengan membagi total belanja dengan PDRB Harga konstan pada masing-masing pemerintah kabupaten atau kota. Ukuran pemerintahan memiliki nilai koefisien regresi yaitu 0,260 dan tingkat signifikansi 0,135 yang lebih dari 0,05 sehingga dapat dikatakan bahwa ukuran pemerintahan tidak memiliki pengaruh terhadap tingkat korupsi di pemerintahan daerah. Hasil ini sama dengan penelitian yang dilakukan oleh Liu dan Lin (2012) bahwa ada hubungan positif ukuran pemerintahan dengan tingkat korupsi. Dengan banyaknya belanja daerah maka akan semakin besar pula potensi kecurangan maupun penyelewengan yang bisa menyebabkan tindakan korupsi terjadi (Henderson \& Kuncoro, 2011).

\section{SIMPULAN DAN SARAN}

Hasil penelitian ini menunjukkan bahwa temuan audit yang diproksikan dengan menggunakan jumlah temuan audit baik temuan atas sistem pengendalian internal maupun temuan atas ketidakpatuhan terhadap perundang-undangan memiliki pengaruh positif dan signifikan terhadap tingkat korupsi. Hasil lainnya adalah pengujian variabel opini audit yang diberikan oleh BPK mempunyai kesimpulan bahwa opini audit tidak berpengaruh terhadap tingkat korupsi. Namun, penelitian ini juga memiliki keterbatasan seperti hanya menggunakan pemerintah daerah kabupaten dan kota dalam Provinsi Jawa Tengah sebagai sampel penelitian serta tahun pengamatan dalam penelitian ini terbatas hanya 4 tahun sehingga, hasil dari penelitian ini mungkin akan berbeda untuk provinsi-provinsi lain di Indonesia. Faktor-faktor yang digunakan sebagai variabel independen untuk mengetahui seberapa jauh pengaruhnya terhadap tingkat korupsi hanyalah temuan audit dan opini audit. Hal ini dikarenakan keterbatasan data yang diizinkan untuk diakses oleh penulis. Penelitian selanjutnya harus menambah faktor-faktor lain untuk melengkapi penelitian ini mengingat nilai adjusted $R$ square penelitian ini sebesar $29,4 \%$ yang mengindikasikan adanya faktor-faktor lain yang tidak terdapat dalam penelitian ini masih mempunyai banyak kemungkinan dalam mempengaruhi tingkat korupsi.

\section{DAFTAR RUJUKAN}

Afriyanti, D., Sabanu, H. G., \& Noor, F. 2015. Penilaian Indeks Akuntabilitas Instansi Pemerintah. Jurnal Tata Kelola Dan A Kuntabilitas Keuangan Negara, 1(1), 21-42.

Agustiningsih, S. W., Murni, S., \& Putri, G. A. 2017. Audit Findings , Local Government Characteristics, and Local Government Financial Statement Disclosure. Review of Integrative Business and Economics Research, 6(3), 179-187.

Ant. 2016. Sejarawan Inggris: Kerugian Indonesia Akibat Korupsi Capai Rp205 Triliun : Okezone News. Retrieved October 11, 2018, from https://news.okezone.com/ $\mathrm{read} / 2016 / 10 / 14 / 337 / 1514892 /$ sejarawan-inggris-kerugian-indonesia-akibat-korupsi-capairp205-triliun

BPKP. 2018. Laporan Kinerja Tahun 2017. Jawa Tengah.

Deny, S. 2018. Isi Lengkap Pidato Kenegaraan Jokowi di DPR RI - Bisnis Liputan6.com. Retrieved September 21, 2018, from https://www.liputan6.com/bisnis/read/3620739/isilengkap-pidato-kenegaraan-jokowi-di-dpr-ri

Dwiputrianti. 2008. The Effectiveness of Auditing Finding Reports in Performing Fiscal Transparency and Accountability Reform in Public Sector (2001-2008) in Indonesia. Journal 
of Administrative Sciences, 5(4).

Ferraz, C., \& Finan, F. 2010. Electoral Accountability and Corruption: Evidence from the Audits of Local Governments $\square$.

Ghozali, I. 2011. Aplikasi Analisis Multivariate Dengan Program IBM SPSS 19. Semarang: Badan Penerbit Universitas Diponegoro.

Gong, T. 2009. Audit for Accountability in China: An Incomplete, 68. https://doi.org/10.1111/ j.1467-8500.2009.00617.x

Gupta, S., Davoodi, H., \& Alonso-terme, R. 2002. Does corruption affect income inequality and poverty?, 23-45.

Henderson, J. V., \& Kuncoro, A. 2011. Corruption and local democratization in Indonesia: The role of Islamic parties. Journal of Development Economics, 94(2), 164-180. https:// doi.org/10.1016/j.jdeveco.2010.01.007

Huefner, R. J. 2011. Fraud Risks in Local Government : An Analysis of Audit Findings, 3(3), 111 -125 .

Indonesia Corruption Watch. (2017). Tren Penindakan Kasus Korupsi Tahun 2017. Jakarta.

Iskandar, R. A. (2018). Indeks Persepsi Korupsi Indonesia 2017 Stagnan, Tetap di Skor 37 - News Liputan6.com. Retrieved October 11, 2018, from https://www.liputan6.com/news/ $\mathrm{read} / 3311878 /$ indeks-persepsi-korupsi-indonesia-2017-stagnan-tetap-di-skor-37

Klitgaard, R. 1997. Cleaning up and invigorating the civil service, 17, 487-509.

Komisi Pemberantasan Korupsi. 2006. MEMAHAMI UNTUK MEMBASMI Buku Panduan untuk Memahami Tindak Pidana Korupsi. Jakarta: Komisi Pemberantasan Korupsi. Retrieved from www.kpk.go.id

Laffan, B., \& Laffan, B. (2011). Auditing and accountability in the European Union Auditing and accountability in the European Union, (October 2014), 37-41. https:// doi.org/10.1080/1350176032000124078

Lessmann, C., \& Markwardt, G. 2010. One Size Fits All ? Decentralization , Corruption , and the Monitoring of Bureaucrats. World Development, 38(4), 631-646. https://doi.org/10.1016/ j.worlddev.2009.11.003

Liu, J., \& Lin, B. 2012. Government auditing and corruption control : Evidence from China's provincial panel data. China Journal of Accounting Research, 5(2), 163-186. https:// doi.org/10.1016/j.cjar.2012.01.002

Mardiasmo. 2009. A kuntansi Sektor Publik. Yogyakarta: CV ANDI OFFSET.

Maulani, A. 2010. Korupsi dan Wajah Kusam Otonomi Daerah. Retrieved September 27, 2018, from https://antikorupsi.org/id/news/korupsi-dan-wajah-kusam-otonomi-daerah

Moisiu, A. 2014. Decentralization and the Increased autonomy in Local Governments. Procedia Social and Behavioral Sciences, 109, 459-463. https://doi.org/10.1016/j.sbspro.2013.12.490

Monteduro, F., Hinna, A., \& Moi, S. 2016. Governance and Corruption in the Public Sector: An Extended Literature Review (pp. 31-51). https://doi.org/10.1108/S2051663020160000005002

Muliana, V. A. 2017. Daftar Negara Paling Korup se-Asia Pasifik, RI Nomor Berapa? - Bisnis Liputan6.com. Retrieved September 27, 2018, from https://www.liputan6.com/bisnis/read/ 2836949/daftar-negara-paling-korup-se-asia-pasifik-ri-nomor-berapa

Olken, B. A. 2007. Monitoring Corruption : Evidence from a Field Experiment in Indonesia, 115 (2).

Prabowo, H. Y. 2016. Sight beyond sight: foreseeing corruption in the Indonesian government through behavioral analysis. Journal of Financial Crime, 23(2), 289-316.

Raman, K. K., \& Wilson, E. R. 2014. Governmental Audit Procurement Practices and Seasoned Bond Prices. The Accounting Review, 69(4), 517-538.

Shah, A. 2007. Performance Accountability and Combating Corruption. (A. Shah, Ed.). Washington, DC: The World Bank. https://doi.org/10.1596/978-0-8213-6941-8

Sherlock, S. 2010. Combating Corruption in Indonesia? The Ombudsman and the Assets Auditing Commission. Bulletin of Indonesian Economc Studies, 38(October 2014), 37-41. https://doi.org/10.1080/00074910215532

Suhardjanto, D. 2018. Accountability and Corruption Level of Provincial Government in Indonesia. Review of Integrative Business and Economic Research, 7(3), 281-296.

Transparency International. 2017. Corruption Perceptions Index 2017: Global Scores.

Tuanakotta, M. 2012. Akuntansi Forensik dan A udit Investigasi (2nd ed.). Jakarta: Salemba Empat Jakarta.

Wardah, F. 2013. ICW: Otonomi Daerah Picu Korupsi Kepala Daerah. Retrieved October 11, 
2018, from https://www.voaindonesia.com/a/icw-otonomi-daerah-picu-korupsi-kepaladaerah/1690178.html 